\begin{tabular}{|c|c|c|}
\hline (j) & $\begin{array}{c}\text { Türkiye Tarımsal Araştırmalar Dergisi } \\
\text { dergipark.org.tr/tutad }\end{array}$ & $\begin{array}{l}\text { Turk J Agric Res } \\
\text { 2020, 7(1): 78-84 } \\
\text { @ TÜTAD } \\
\text { ISSN: 2148-2306 }\end{array}$ \\
\hline $\begin{array}{l}\text { UNIVERSITESI } \\
\text { Bilumin Osümula }\end{array}$ & Research Article & $\begin{array}{l}\text { e-ISSN: } 2528-858 X \\
\text { doi: } 10.19159 / \text { tutad.668185 }\end{array}$ \\
\hline
\end{tabular}

\title{
Effect of Grain Size on The Root System Architecture of Bread Wheat (Triticum aestivum L.)
}

\author{
Harun BEKTAŞ ${ }^{1 *}$, John Giles WAINES ${ }^{2}$ \\ ${ }^{1}$ Siirt University, Faculty of Agriculture, Department of Agricultural Biotechnology, Siirt, TURKEY \\ ${ }^{2}$ University of California, Riverside Department of Botany and Plant Sciences, Riverside, CA 92521, USA
}

\begin{tabular}{ll}
\hline \multicolumn{1}{c}{ Received: 31.12 .2019} & Accepted: 16.02 .2020 \\
\hline ORCID ID (by author order) & \\
(D) orcid.org/0000-0002-4397-4089 (D) orcid.org/0000-0002-7341-7312 & \\
"Corresponding Author: bektasharun@gmail.com
\end{tabular}

\begin{abstract}
The aim of this study was to investigate the role of grain size on seedling root architecture. Ten different bread wheat cultivars were selected to examine the effect of grain size on primary root traits under controlled conditions. Seminal root traits were tested with germination papers at the growth stage 1. Significant differences between seminal root number, total seminal root length, longest root length, and root growth angle were observed among 10 cultivars. The seminal root number per plant was found to be 3.93 in the large, 3.71 in the medium and 3.20 in the small grain groups. Similar rankings in the seminal root length were observed, while root growth angle did not follow the same trend. The study suggested that the cultivar Atay 85 with superior primary root traits can be an advantage, especially in regions where plants achieve an advantage at a deep soil water level, under water stress at early growth stages.
\end{abstract}

Keywords: Root architecture, grain size, bread wheat, seminal root length, seminal root angle

\section{Introduction}

Bread wheat (Triticum aestivum L.) is a staple crop and is cultivated on almost every continent. Wheat production reached 771 million metric tons by 2017 across the world, equaling approximately $20 \%$ of daily caloric intake (Anonymous, 2017). The human population is expected to increase to 9 billion by 2050 and the need for increased yield in almost every crop becomes an urgent issue. Loss of arable lands due to salinity, flood, drought, erosion, and development worsens the situation (Döös, 2002). Average global wheat production is not even close to the genetic potential, with an average yield of 2 tons hectare ${ }^{-1}$, it is less than one-third of potential 7 tons hectare ${ }^{-1}$ (Anderson, 2010; Hawkesford et al., 2013).

Plant breeders are facing new challenges to cope with biological and abiotic stresses. The efforts to find new genetic variation and novel allelic diversity is an important and continuous issue. Wheat breeding goals have shifted from straw and quality traits to mostly grain yield by increasing harvest index. Breeders concentrated on maximum grain yield by increasing fertilizer and water use efficiencies as well as disease resistance especially after the Green Revolution (Hedden, 2003). According to an estimate (Jaradat, 2013), the domestication syndrome, modern breeding and monoculture production systems caused a loss of genetic diversity up to $70 \%$. Evaluation of cultivars, landraces and wild relatives need to become a daily practice for all breeder and geneticist.

Turkey has a significant genetic variation for almost every need of wheat breeding, due to being home of domestication. Some of the old cultivars or selected varieties (selected from landraces) are still preferred by farmers for high straw yield and yield stability under low input conditions (Karagöz, 2014). Therefore, any possible use of the allelic diversity available in some old or relatively old varieties is of paramount importance to enhance the speed of plant breeding.

The bread wheat root system consists of seminal and nodal roots. Wheat and their relatives in the 
Triticeae tribe have up to 10 embryonic seminal roots, though most wheat has 3-5 seminal roots (Robertson et al., 1979). Even though seminal roots and nodal roots specialize in water and nutrient uptake, respectively, as well as anchoring the plant, almost all roots take multiple roles commonly in all monocots. Studying the root system was a neglected area for a long time, until recent years. Over the last decade, many studies have been published on plant root development, but still many aspects of it are lacking (Passioura, 1983; Kätterer et al., 1993; Lynch, 2007, 2013; Waines and Ehdaie, 2007; Manschadi et al., 2008; Sharma et al., 2010; De Smet et al., 2012; Akman and Topal, 2013; Allard et al., 2013; Kong et al., 2013; Atkinson, 2015; Lynch and Wojciechowski, 2015).

Grain size has always been at the center of attention for breeders, which is related to both grain yield and thousand grain/kernel weight (TGW or TKW). However, interestingly the interaction between grain weight and root system traits is rarely studied (Robertson et al., 1979, Manske and Vlek, 2002). Genetic variation for root system architecture is studied often, but the effect of grain size on root system architecture within and between genotypes is not well studied and needs in-depth evaluation.

This study aimed to identify the effect of grain size (endosperm size) on the seedling root architectural traits. Specifically, interactions between individual grain size and root architecture traits (seminal root number and length, the longest root length and root growth angle) within and between different wheat cultivars were investigated.

\section{Materials and Methods}

\subsection{Plant material}

Modern bread wheat (T. aestivum L.) cultivars and some historically important old varieties (direct selected from landraces) were evaluated to elucidate the role of grain size on seedling root system architecture within a wide genetic background. Plant material used in this study consisted of nine cultivars from Turkish bread wheat germplasm namely, Ak 702, Köse 220-39, Bezostaja 1, Gerek 79, Kırkpınar 79, Atay 85, Üveyik, Uzunyayla, and Mizrak. Pedigree information of each cultivar is listed on Bektas et al. (2016). They were selected to represent the Turkish bread wheat historical gene pool and breeding timeline. One reference cultivar (Pavon 76) from the International Maize and Wheat Improvement Center (CIMMYT) was selected as control due to significant knowledge on its root system.

\subsection{Plant growth and root image analysis}

Selected genotypes were screened for root traits by using a modified cigar roll method of Zhu et al. (2006). A system designed by the authors, inspired by growth pouches (Anonymous, 2019), a gelbased system of Bengough et al. (2004) and the cigar roll method of Zhu et al. (2006). The system consists of two plexiglass plates $(20 \times 30 \mathrm{~cm})$ fitted with spacers, holding germination papers, and standing in a tub filled with distilled water (Figure $1)$.

Grains from each genotype were weighed with a precision scale to get the exact weights of each individual grain. Grains then classified according to

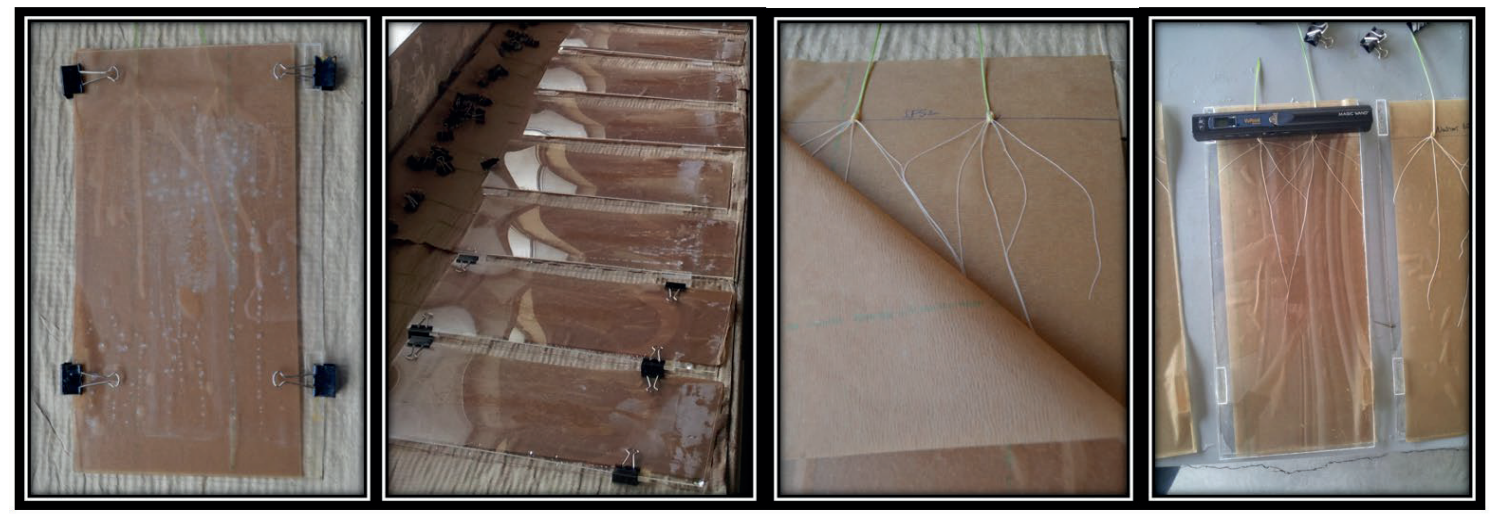

Figure 1. Roots were scanned by a handheld scanner after removal of germination papers after 7 days of growth in distilled water

Plexiglass system consists of two layers of germination paper, fitted between two Plexi plates with spacers. Scanned with a document scanner.

their weights as large $=\mathrm{L}(\sim 0.05 \mathrm{~g})$, medium $=\mathrm{M}$ $(\sim 0.03-0.04 \mathrm{~g})$, and small $=\mathrm{S}(\sim 0.02 \mathrm{~g})$ within each genotype. Grains were surface sterilizedwith $\% 1$ sodium hypochlorite $(\mathrm{NaClO})$ for 10 minutes and rinsed with distilled water at least 3 times. Each grain was imbibed in water for $24 \mathrm{~h}$ prior to the 
study for germination. Each grain is numerated and placed between two wet germination papers. Tubs were filled with distilled water and seedlings were let to grow in the glasshouse at the University of California, Riverside. Experiments were set up in a randomized complete block design with three replications where replications were treated as blocks. Each replication had two plants for each genotype.

The study was run for seven days, after which the plexiglass plates were separated, each seedling was scanned with a handheld digital scanner (VuPoint Solutions, Magic Wand PDS-ST415VPS) with 300 DPI image quality and saved to PC for image analysis using ImageJ software (Schneider et al., 2012). Data for seedling root traits namely, seminal root number (SRN), total seminal root length (SRL), longest root length (LRL), and root growth angle (RA) were collected. Root growth angle was measured for the angle between the first pair of roots around the primary root.

\subsection{Statistical analysis}

Analysis of variance (ANOVA) was performed to determine the variation for grain size and genotype. Statistical analyses were performed using the Statistix software (Analytical Software; Tallahassee, FL, USA). Pearson correlation analysis was performed for interactions between traits of interest. Tukey's Honest Significant Difference (HSD) and least significant difference (LSD) tests were performed to see the grouping structure for both genotypes and between grain size groups (Steel et al., 1997).

\section{Results and Discussion}

Harvest index and yield components are always considered as major traits of importance for breeders and included in almost every breeding project. Grain size, which is mostly evaluated as thousand grain/kernel weight (TGW) is one of the most important yield components considered by breeders. Here we aimed to understand the role of TGW on root system architecture with ten different bread wheat cultivars. Nine cultivars widely-grown in Turkey and one reference cultivar (Pavon 76) were weighted with precision scaling (by weighing each grain) and evaluated for root traits, to indicate the role of endosperm size in early root development and the variation within and between cultivars. When the literature was evaluated, there were many studies evaluating some aspects of grain size on mostly above-ground traits. Many studies generally consider hundred or TGW even only as mean values (Arnott, 1969; Edwards and Hartwig, 1971; Cideciyan and Malloch, 1982; Hendrix,
1984; Marshall, 1986; Gonzalez, 1993; Mian and Nafiger, 1994; Moshatati and Gharineh, 2012). Here individual grain weighting approach is applied to highlight the role of endosperm size on seminal root architecture.

Significant genetic variation $(p<0.01)$ were observed for all traits evaluated. The study concentrated on seedling root architecture, due to its importance on early vigorous growth. Seminal root number, total seminal root length, and the longest root length (primary root length) are common parameters in seedling studies and here some interesting roles of grain size on these parameters (Figure 2) were observed. Detailed ranking of all genotypes and grain sizes compared to each other can be seen in Figure 2. By listing all grains, it was possible to see the inter and intra genetic variation and the role of endosperm on it. Genetic differences between cultivars and the variation on grain size together interacted and affected all four root parameters. By only evaluating genotypes without considering the grain size, some factors that are effective on seminal root parameters may be missed.

Significant genotypic variation $(\mathrm{p}<0.01)$ was seen on the SRN, and SRL when 10 cultivars were evaluated. The maximum number of roots per plant according to average data was seen in Atay 85 (4.5), while the lowest was in Mizrak (3.17). Similarly, SRL was the highest on Atay $85(69.80 \mathrm{~cm})$ and the lowest SRL was on Mizrak (49.60 cm). When LRL (primary or whichever root is the longest) were evaluated, Pavon 76 had the longest root $(29.15 \mathrm{~cm})$ and Mizrak had the shortest root length $(20.36 \mathrm{~cm})$ compared to others. The root growth angle was significantly different $(p<0.001)$ between genotypes and the widest root growth angle was in Ak $702\left(51.68^{\circ}\right)$ while the narrowest was in Pavon $76\left(32.70^{\circ}\right)$ (Table 1).

The role of grain size (endosperm size) was evaluated and according to results, significant differences were seen on all parameters $(p<0.05)$. The grouping was similar for SRN and SRL as $\mathrm{L}>\mathrm{M}>\mathrm{S}$, it was $\mathrm{M}>\mathrm{L}>\mathrm{S}$ for $\mathrm{LRL}$, and $\mathrm{S}>\mathrm{L}>\mathrm{M}$ for RA. Overall when all genotypes were grouped according to grain weight, SRN was 3.93 for L, 3.71 for $M$ and 3.20 for $S$ grain size group. Similarly, SRL was the highest on $\mathrm{L}$ and the lowest on $\mathrm{S}$ grain size group. However, there was a switch on rankings for LRL, where the longest roots were on M ( $26.38 \mathrm{~cm}$ average), followed closely by $\mathrm{L}(25.32$ $\mathrm{cm}$ average) and $\mathrm{S}$ was the shortest with $22.81 \mathrm{~cm}$ average. The root growth angle did not follow the trend of other traits, the widest root growth angle was on group $\mathrm{S}\left(47.12^{\circ}\right)$, while the narrowest was in group $\mathrm{M}\left(43.03^{\circ}\right)$ (Table 2). 


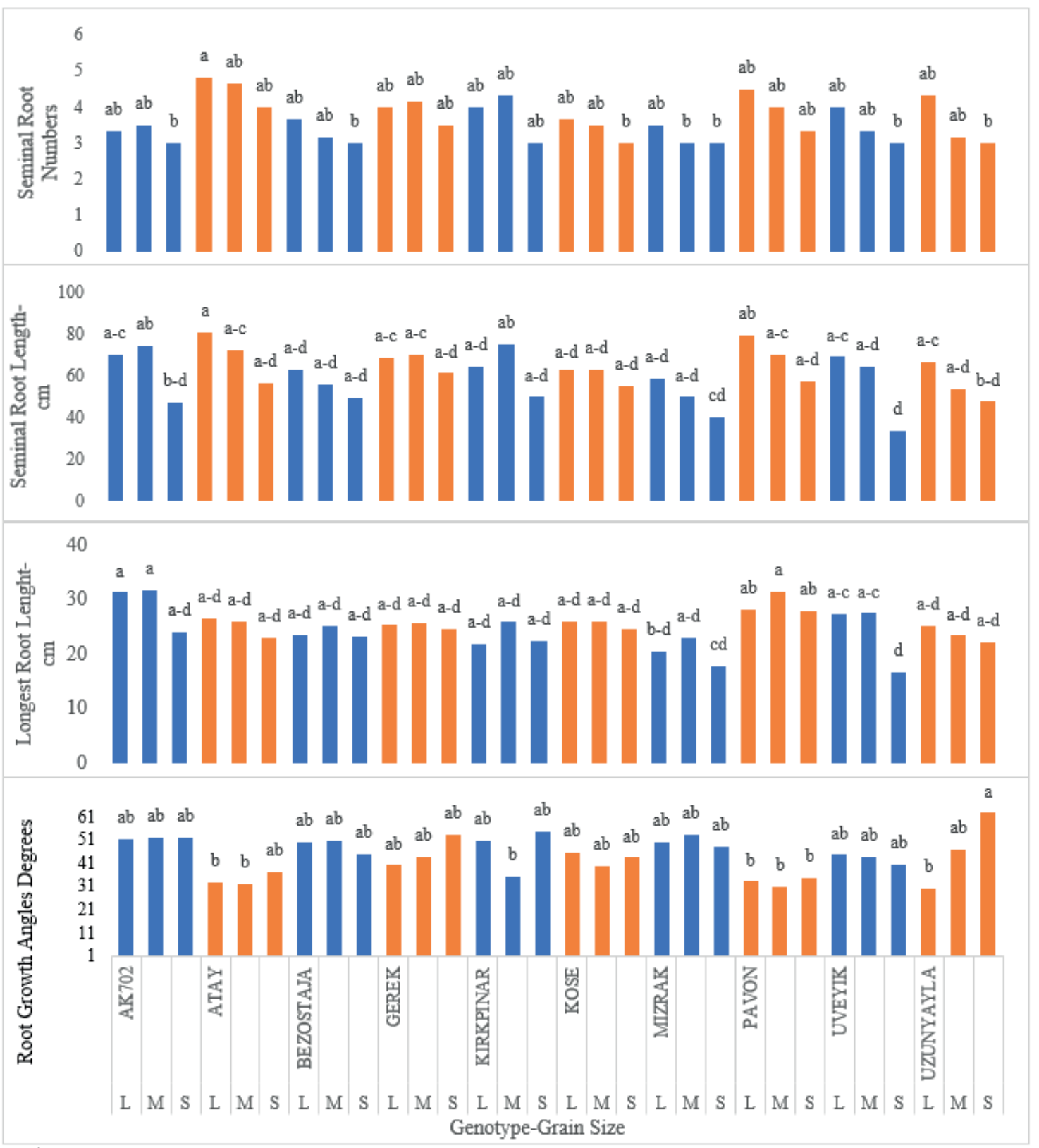

Figure 2. Genetic variation for: Seminal root number (SRN), length (SRL), longest root length (LRL), and root growth angle (RA) within each genotype and comparison with others

L: Large ( $\sim 0.05 \mathrm{~g})$, M: Medium ( 0.03-0.04 g), S: Small $(\sim 0.02 \mathrm{~g})$ grain weight. Means followed by different letters within columns are different according to Tukey's HSD test at $\mathrm{p}<0.05$

When we evaluated each genotype and grain size separately, there were 30 separate groups (3 size groups for each genotype $\mathrm{x} 10$ genotypes). Atay $85-\mathrm{L}$ was the top cultivar with the highest SRN and SRL values, while Ak 702-M was was ranked in the top for LRL and Uzunyayla-S was top for RA. The rest of the order is summarized in Figure 2. According to Tukey's HSD test, there were 2 to 4 groups for mean values. Four major groups were seen on SRL and LRL and two groups were seen in SRN and RA (Figure 2).
Correlation coefficient values supported general outcomes, with a significant correlation between grain size and SRN $\left(0.46^{*}\right)$, and grain size and SRL $\left(0.55^{*}\right)$. However, there was a weak positive correlation between grain size and LRL (0.28) and a weak negative correlation between grain size and RA (-0.17) (Table 3). These data indicate that mean values followed a similar trend, either separately (each genotype) or combined (all 10 genotypes), and grain size significantly affects early root growth. There were previous reports of 
Table 1. Mean values per plant for seminal root number, seminal root length, longest root length and root growth angle for nine Turkish and one CIMMYT bread wheat cultivars grown in germination papers

\begin{tabular}{lcccc}
\hline Cultivars & SRN & $\begin{array}{l}\text { SRL } \\
(\mathrm{cm})\end{array}$ & $\begin{array}{c}\text { LRL } \\
(\mathrm{cm})\end{array}$ & $\begin{array}{c}\text { RA } \\
(\text { o degrees })\end{array}$ \\
\hline Ak 702 & $3.28 \mathrm{~b}$ & $63.87 \mathrm{ab}$ & $29.00 \mathrm{a}$ & $51.67 \mathrm{a}$ \\
Atay 85 & $4.50 \mathrm{a}$ & $69.80 \mathrm{a}$ & $25.10 \mathrm{abc}$ & $33.93 \mathrm{bc}$ \\
Bezostaja 1 & $3.28 \mathrm{~b}$ & $56.15 \mathrm{ab}$ & $23.96 \mathrm{bc}$ & $48.47 \mathrm{a}$ \\
Gerek 79 & $3.89 \mathrm{ab}$ & $66.50 \mathrm{a}$ & $25.23 \mathrm{abc}$ & $45.53 \mathrm{abc}$ \\
Kirkpınar 79 $3.78 \mathrm{ab}$ & $63.11 \mathrm{ab}$ & $23.36 \mathrm{bc}$ & $46.87 \mathrm{ab}$ \\
Köse 220-39 3.39 b & $60.43 \mathrm{ab}$ & $25.54 \mathrm{ab}$ & $42.77 \mathrm{abc}$ \\
Mizrak & $3.17 \mathrm{~b}$ & $49.60 \mathrm{~b}$ & $20.35 \mathrm{c}$ & $50.39 \mathrm{a}$ \\
Pavon 76 & $3.94 \mathrm{ab}$ & $68.76 \mathrm{a}$ & $29.15 \mathrm{a}$ & $32.70 \mathrm{c}$ \\
Üveyik & $3.44 \mathrm{~b}$ & $55.55 \mathrm{ab}$ & $23.86 \mathrm{bc}$ & $42.81 \mathrm{abc}$ \\
Uzunyayla & $3.50 \mathrm{~b}$ & $55.83 \mathrm{ab}$ & $23.51 \mathrm{bc}$ & $46.56 \mathrm{abc}$ \\
\hline Std. er.-1 & 0.18 & 3.38 & 1.08 & 3.05 \\
\hline Std. er.-2 & 0.25 & 4.79 & 1.52 & 4.31 \\
\hline
\end{tabular}

SRN: Seminal root number, SRL: Seminal root length, LRL: Longest roo Length, RA: Root growth angle, Means followed by different letters within columns are different according to Tukey's HSD test at $\mathrm{p}<0.05$, Std. er-1: Standard error of a mean, Std. er-2: Standard error (difference of 2 means)

Table 2. Tukey's HSD all-pairwise comparisons for grain size groups

\begin{tabular}{|c|c|}
\hline Grain size group & Mean \\
\hline \multicolumn{2}{|c|}{ Seminal root number } \\
\hline $\mathrm{L}$ & $3.93 \mathrm{a}$ \\
\hline M & $3.72 \mathrm{a}$ \\
\hline $\mathrm{S}$ & $3.20 \mathrm{~b}$ \\
\hline \multicolumn{2}{|c|}{ Seminal root length $(\mathrm{cm})$} \\
\hline $\mathrm{L}$ & $67.78 \mathrm{a}$ \\
\hline M & $65.12 \mathrm{a}$ \\
\hline $\mathrm{S}$ & $50.68 \mathrm{~b}$ \\
\hline \multicolumn{2}{|c|}{ Longest root length $(\mathrm{cm})$} \\
\hline M & $26.38 \mathrm{a}$ \\
\hline $\mathrm{L}$ & $25.32 \mathrm{a}$ \\
\hline $\mathrm{S}$ & $22.81 \mathrm{~b}$ \\
\hline \multicolumn{2}{|c|}{ Root growth angle ( ${ }^{\circ}$ degrees $)$} \\
\hline $\mathrm{S}$ & $47.12 \mathrm{a}$ \\
\hline $\mathrm{L}$ & $44.00 \mathrm{a}$ \\
\hline M & $43.03 \mathrm{a}$ \\
\hline
\end{tabular}

Table 3. Correlation coefficients (Pearson) between grain size and seminal root number, seminal root length, longest root length and root growth angle

\begin{tabular}{lcrrl}
\hline & \multicolumn{1}{c}{ SRN } & \multicolumn{1}{l}{ SRL } & \multicolumn{1}{c}{ LRL } & RA \\
\hline SRL & $0.7872^{*}$ & & & \\
LRL & 0.3513 & $0.7242^{*}$ & & \\
RA & $-0.5994^{*}$ & $-0.4635^{*}$ & -0.3040 & \\
Grain size & $0.4643^{*}$ & $0.5457^{*}$ & 0.2773 & -0.1666 \\
\hline
\end{tabular}

SRN: Seminal root number, SRL: Seminal root length, LRL: Longest root Length, RA: Root growth angle (RA). *: Significant for $\mathrm{p}<0.05$

thousand/hundred grain weight on some seedling growth parameters (Arnott, 1969; Edwards and Hartwig, 1971; Cideciyan and Malloch, 1982; Hendrix, 1984; Marshall, 1986; Gonzalez, 1993; Mian and Nafiger, 1994; Moshatati and Gharineh,
2012). Many of the above studies suggested a strong interaction between grain size (either as TGW, hundred-grain weight or other classification) and vigorous seedling growth including fast root development. It is always hypothesized that a large endosperm can support germination for a longer period than smaller endosperms. We cannot make a direct comparison with previous observations since none had data for individual grain weights.

Studying root system architecture has many aspects/techniques, including but not limited to, shovelomics, gel observation chambers, growth pouches, pot or PVC tube systems, hydroponics minirhizotrons etc. (Bengough et al., 2004; Ehdaie and Waines, 2006; Trachsel et al., 2011; Topp et al., 2013; Richard et al., 2015). The seedling plate system (Figure 1) is a quick and practical approach with easy setup and fast processing. One of the main advantages compared to growth pouch system is reduced root tip penetration, growth pouches or cigar roll methods have some level of pressure on root tips and on root growth angle, however, the seedling plate system has enough space for root tips and roots to grow freely without any limitation. Seedling root growth parameters were evaluated with this system and there was a slightly negative correlation between grain size and RA, which may be due to the heritability of RA or other differences between cultivars (Jia et al., 2019). According to Uga et al. (2011), one Quantitative Trait Loci (QTL) explained $66.6 \%$ of the phenotypic variation in the rice root growth angle. The gene, Drol, effecting RA was cloned by the same team (Uga et al., 2013). Their observations suggest a strong change in RA by a deletion of the coding region. This suggests a more qualitative nature of this trait, influenced mostly by gravity (Uga et al., 2013), compared to the other three traits we evaluated. Even though there was no direct interaction between grain size and root growth angle in this study, RA is a good candidate trait for selection in breeding due to its qualitative heritability.

The results observed here were a preliminary study to understanding the role of grain size on early root growth. The number of cultivars was limited due to the hard process of weighting each grain and tracking. We believe that future studies with more cultivars, replications and on other species will enhance the knowledge of the importance and role of grain size/TGW in breeding for cultivars with early enhanced growth and maybe drought tolerance at the seedling stage.

\section{Conclusions}

As a result, it has been observed that different wheat genotypes have quite different root architectures, 
and grain size affects SRN and SRL positively. However, Tukey's HSD test results were disputed in terms of LRL $(\mathrm{M}>\mathrm{L}>\mathrm{S})$ and RA $(\mathrm{S}>\mathrm{L}>\mathrm{M})$ parameters. Atay 85 was superior to other cultivars with the highest SRN and SRL mean values. The effect of grain size on RA is complicated due to the high heritability of the trait. There is a need for an in-depth evaluation of grain size RA interaction. Selection for large grain size and identifying phenotypic and genotypic variation on root system traits may enhance abiotic stress tolerance in wheat. Extensive root development before flowering/anthesis can be an advantage, especially in regions with a deep soil water level, and the plant can gain from advanced rooting in water-stressed areas at early stages.

\section{Acknowledgments}

We are grateful to Nageen Asadi for technical support on experiments. This work was supported by the University of California Riverside, Botanic Gardens, The California Agricultural Experiment Station, and a doctoral fellowship of the Turkish Republic Ministry of National Education to Harun Bektaş.

\section{References}

Akman, H., Topal, A., 2013. Effects on wheat root growth and development of rhizosphere environment and stress factors. Journal of Selcuk University Natural and Applied Science, 2(ICOEST Special Issue): 824838.

Allard, V., Martre, P., Le Gouis, J., 2013. Genetic variability in biomass allocation to roots in wheat is mainly related to crop tillering dynamics and nitrogen status. European Journal of Agronomy, 46: 68-76.

Anderson, W.K., 2010. Closing the gap between actual and potential yield of rainfed wheat. The impacts of environment, management and cultivar. Field Crops Research, 116(1-2): 14-22.

Anonymous, 2017. Crop Production Indicators. The Food and Agriculture Organization Corporate Statistical Database (FAOSTAT), Rome, Italy.

Anonymous, 2019. Mega International. (https://megainternational.com/), (Access date: 23.12.2019).

Arnott, R.A., 1969. The effect of seed weight and depth of sowing on the emergence and early seedling growth of perennial ryegrass (Lolium perenne). Grass and Forage Science, 24(2): 104-110.

Atkinson, J., 2015. Phenotyping wheat root architecture in 2D and 3D. PAG XXIII Conference, 10-14 January, San Diego, CA, USA.

Bektas, H., Hohn, C.E., Waines, J.G., 2016. Root and shoot traits of bread wheat (Triticum aestivum L.) landraces and cultivars. Euphytica, 212(2): 297-311.

Bengough, A.G., Gordon, D.C., Al-Menaie, H., Ellis, R.P., Allan, D., Keith, R., Thomas, W.T.B., Forster, B.P., 2004. Gel observation chamber for rapid screening of root traits in cereal seedlings. Plant and Soil, 262(1-2): 63-70.

Cideciyan, M.A., Malloch, A.J., 1982. Effects of seed size on the germination, growth and competitive ability of Rumex crispus and Rumex obtusifolius. The Journal of Ecology, 70(1): 227-232.

De Smet, I., White, P.J., Bengough, A.G., Dupuy, L., Parizot, B., Casimiro, I., Heidstra, R., Laskowski, M., Lepetit, M., Hochholdinger, F., Draye, X., 2012. Analyzing lateral root development: how to move forward. The Plant Cell, 24(1): 15-20.

Döös, B.R., 2002. Population growth and loss of arable land. Global Environmental Change, 12(4): 303-311.

Edwards, C.J., Hartwig, E.E., 1971. Effect of seed size upon rate of germination in soybeans 1. Agronomy Journal, 63(3): 429-450.

Ehdaie, B., Waines, J.C., 2006. Determination of a chromosome segment influencing rooting ability in wheat-rye 1BS-1RS recombinant lines (Triticum aestivum L.; Secale cereale L.). Journal of Genetics and Breeding, 60(1): 71-76.

Gonzalez, E.J., 1993. Effect of seed size on germination and seedling vigor of Virola koschnyi Warb. Forest Ecology and Management, 57(1-4): 275-281.

Hawkesford, M.J., Araus, J.L., Park, R., Calderini, D., Miralles, D., Shen, T., Zhang, J., Parry, M.A.J., 2013. Prospects of doubling global wheat yields. Food Energy Security, 2(1): 34-48.

Hedden, P., 2003. The genes of the Green Revolution. Trends in Genetics, 19(1): 5-9.

Hendrix, S.D., 1984. Variation in seed weight and its effects on germination in Pastinaca sativa L. (Umbelliferae). American Journal of Botany, 71(6): 795-802.

Jaradat, A.A., 2013. Wheat landraces: A mini review. Emirates Journal of Food and Agriculture, 25(1): 2029.

Jia, Z., Liu, Y., Gruber, B. D., Neumann, K., Kilian, B., Graner, A., von Wirén, N. 2019. Genetic dissection of root system architectural traits in spring barley. Frontiers in Plant Science, 10: 1-14.

Karagöz, A., 2014. Wheat landraces of Turkey. Emirates Journal of Food and Agriculture, 26(2): 149-156.

Kätterer, T., Hansson, A.C., Andrén, O., 1993. Wheat root biomass and nitrogen dynamics effects of daily irrigation and fertilization. Plant and Soil, 151(1): 2130.

Kong, L., Si, J., Sun, M., Feng, B., Zhang, B., Li, S., Wang, Z., Wang, F., 2013. Deep roots are pivotal for regulating post-anthesis leaf senescence in wheat (Triticum aestivum L.). Journal of Agronomy and Crop Science, 199(3): 209-216.

Lynch, J.P., 2007. Roots of the second green revolution. Australian Journal of Botany, 55(5): 493-512.

Lynch, J.P., 2013. Steep, cheap and deep: an ideotype to optimize water and $\mathrm{N}$ acquisition by maize root systems. Annals of Botany, 112(2): 347-357.

Lynch, J.P., Wojciechowski, T., 2015. Opportunities and challenges in the subsoil: pathways to deeper rooted 
crops. Journal of Experimental Botany, 66(8): 2199 2210.

Manschadi, A.M., Hammer, G.L., Christopher, J.T., Devoil, P., 2008. Genotypic variation in seedling root architectural traits and implications for drought adaptation in wheat (Triticum aestivum L.). Plant and Soil, 303(1-2): 115-129.

Manske, G.G., Vlek, P.L., 2002. Plant roots, the hidden half. In Y. Waisel, A. Eshel, T. Beeckman, U. Kafkafi (Eds.), Root Architecture-Wheat as a Model Plant, CRC Press, Boca Raton, pp. 249-259.

Marshall, D.L., 1986. Effect of seed size on seedling success in three species of Sesbania (Fabaceae). American Journal of Botany, 73(4): 457-464.

Mian, M.A.R., Nafziger, E.D., 1994. Seed size and water potential effects on germination and seedling growth of winter wheat. Crop Science, 34(1): 169-171.

Moshatati, A., Gharineh, M.H., 2012. Effect of grain weight on germination and seed vigor of wheat International Journal of Agriculture and Crop Sciences, 4(8): 458-460.

Passioura, J.B., 1983. Roots and drought resistance. Agricultural Water Management, 7(1-3): 265-280.

Richard, C.A., Hickey, L.T., Fletcher, S., Jennings, R., Chenu, K., Christopher, J.T., 2015. High-throughput phenotyping of seminal root traits in wheat. Plant Methods, 11(13): 1-11.

Robertson, B.M., Waines, J.G., Gill, B.S., 1979. Genetic variability for seedling root numbers in wild and domesticated wheats 1. Crop Science, 19(6): 843847.

Schneider, C.A., Rasband, W.S., Eliceiri, K.W., 2012. $\mathrm{NIH}$ image to ImageJ: 25 years of image analysis. Nature Methods, 9(7): 671 .

Sharma, S., DeMason, D.A., Ehdaie, B., Lukaszewski, A.J., Waines, J.G., 2010. Dosage effect of the short arm of chromosome 1 of rye on root morphology and anatomy in bread wheat. Journal of Experimental Botany, 61(10): 2623-2633.

Steel, R.G.D., Torrie, J.H., Dickey, D.A., 1997. Principles and Procedures of Statistics: a Biometrical Approach, McGraw-Hill, New York.

Topp, C.N., Iyer-Pascuzzi, A.S., Anderson, J.T., Lee, C.R., Zurek, P.R., Symonova, O., Zheng, Y., Bucksch, A., Mileyko, Y., Galkovskyi, T., Moore, B.T., 2013. 3D phenotyping and quantitative trait locus mapping identify core regions of the rice genome controlling root architecture. Proceedings of the National Academy of Sciences, 110(18): 16951704.

Trachsel, S., Kaeppler, S.M., Brown, K.M., Lynch, J.P., 2011. Shovelomics: high throughput phenotyping of maize (Zea mays L.) root architecture in the field. Plant and Soil, 341(1-2): 75-87.

Uga, Y., Okuno, K., Yano, M., 2011. Dro1, a major QTL involved in deep rooting of rice under upland field conditions. Journal of Experimental Botany, 62(8): 2485-2494.

Uga, Y., Sugimoto, K., Ogawa, S., Rane, J., Ishitani, M., Hara, N., Kitomi, Y., Inukai, Y., Ono, K., Kanno, N., Inoue, H., 2013. Control of root system architecture by DEEPER ROOTING 1 increases rice yield under drought conditions. Nature Genetics, 45(9): 1097.

Waines, J.G., Ehdaie, B., 2007. Domestication and crop physiology: roots of green-revolution wheat. Annals of Botany, 100(5): 991-998.

Zhu, J., Mickelson, S.M., Kaeppler, S.M., Lynch, J.P., 2006. Detection of quantitative trait loci for seminal root traits in maize (Zea mays L.) seedlings grown under differential phosphorus levels. Theoretical and Applied Genetics, 113(1): 1-10. 